\title{
CYP2C19*1 and CYP2C19*2 Polymorphism in Turkish Patients Being Diagnosed with Stable Coronary Artery Disease and Using Clopidogrel
}

\section{Clopidogrel Kullanan, Koroner Arter Hastalığı Tanısı Mevcut Olan Türk Popülasyonunda CYP2C19*1 ve CYP2C19*2 Gen Polimorfizmi}

\section{(D) Ramazan Sabırlı1, (D Aylin Köseler², (D) Atakan Yılmaz³, (D İsmail Doğu Kılıç4}

${ }^{1}$ Kafkas University Faculty of Medicine, Department of Emergency Medicine, Kars, Turkey

2Pamukkale University Faculty of Medicine, Department of Biophysics, Denizli, Turkey

${ }^{3}$ Pamukkale University Faculty of Medicine, Department of Emergency Medicine, Denizli, Turkey

${ }^{4}$ Pamukkale University Faculty of Medicine, Department of Cardiology, Denizli, Turkey

\section{Abstract}

Objective: The CYP2C19*1 has an entirely normal activity allele whose clopidogrel metabolism is normal. CYP2C19*2 called as non-functional alleles. In this study, we aimed to establish the CYP2C19*1 and CYP2C19*2 genotype frequencies both in Turkish patients with coronary artery disease (CAD), who used clopidogrel, and in healthy Turkish population as well as to present the differences in genotypes and alleles between both groups.

Method: One hundred healthy individuals and 200 patients diagnosed with CAD were included in the study. DNA was isolated and CYP2C19 gene was amplified through the polymerase chain reaction method in the genomic DNAs obtained, and the polymorphic foci in these regions were specified.

Results: CYP2C19*1/1 genotype was identified in 132 patients (66\%), CYP2C19*1/2 genotype in 62 patients (31\%) and CYP2C19*2/2 genotype in 6 patients (3\%) in the CAD group. In the control group, by contrast, 72 patients (72\%) were identified with CYP2C19*1/1 genotype, 20 patients with CYP2C19*1/2 genotype and 8 patients with CYP2C19*2/2 genotype. There was a significant difference between the groups in terms of genotypes $(p=0.034)$.

Conclusion: We found CYP2C19*1/2 and CYP2C19*2/2 genotype to be higher in the CAD patients than in the control group, highlighting the importance of checking CYP2C19 gene polymorphism prior to the initiation of antiplatelet therapy in CAD patients.

Keywords: Clopidogrel metabolism, coronary artery disease, CYP2C19 polymorphism, Turkish population

\section{Öz}

Amaç: CYP2C19*1, klopidogrel metabolizması normal olan tamamen normal bir aktiviteye sahiptir. CYP2C19*2, işlevsel olmayan aleller olarak adlandırıır. Bu çalışmada, hem klopidogrel kullanan ve koroner arter hastalığı (KAH) olan Türk hastalarda hem de sağlıklı Türk popülasyonunda CYP2C19*1 ve CYP2C19*2 genotip frekanslarını belirlemeyi ve her iki grup arasındaki genotip ve alel farklılıklarını sunmayı amaçladık.

Yöntem: Çalışmaya 100 sağlıklı birey ve KAH tanısı almış 200 hasta dahil edildi. DNA izole edilerek ve CYP2C19 geni polimeraz zincirleme reaksiyonu yöntemi ile amplifiye edilerek bu bölgelerdeki polimorfik odaklar belirlendi.

Bulgular: $\mathrm{KAH}$ grubunda 132 hastada (\%66) CYP2C19*1/1 genotipi, 62 hastada (\%31) CYP2C19*1/2 genotipi ve 6 hastada (\%3) CYP2C19*2/2 genotipi tespit edildi. Kontrol grubunda ise 72 hasta (\%72) CYP2C19*1/1 genotipi, 20 hasta CYP2C19*1/2 genotipi ve 8 hasta CYP2C19*2/2 genotipi ile tanımlanmıştır. Genotipler açısından gruplar arasında anlamlı fark vardı $(p=0,034)$.

Sonuç: $\mathrm{KAH}$ hastalarında CYP2C19*1/2 ve CYP2C19*2/2 genotipinin kontrol grubuna göre daha yüksek olduğunu belirledik. Bu da koroner arter hastalarında antiplatelet tedaviye başlamadan önce CYP2C19 gen polimorfizminin bakılmasının önemli olduğunu vurgulamaktadır.

Anahtar kelimeler: CYP2C19 polimorfizmi, klopidogrel metabolizması, koroner arter hastalığı, Türk popülasyonu

Address for Correspondence: Ramazan Sabırlı, Kafkas University Faculty of Medicine, Department of Emergency Medicine, Kars, Turkey E-mail: ramazan_sabirli@hotmail.com ORCID: orcid.org/0000-0003-4599-5833 Received: 12.08.2020 Accepted: 27.11.2020

Cite this article as: Sabırlı R, Köseler A, Yılmaz A, Doğu Kılıç I. CYP2C19*1 and CYP2C19*2 Polymorphism in Turkish Patients Being Diagnosed with Stable Coronary Artery Disease and Using Clopidogrel. Bagcilar Med Bull 2021;6(1):53-60.

${ }^{\odot}$ Copyright 2021 by the Health Sciences University Turkey, Bagcilar Training and Research Hospital Bagcilar Medical Bulletin published by Galenos Publishing House. 


\section{Introduction}

Irreversibly inhibiting the platelet P2Y12 receptor, thienopyridines are used as antithrombotic agents in the treatment of $\mathrm{CAD}$, peripheral vascular and cerebrovascular diseases $(1,2)$. Besides, clopidogrel is known as the most frequently used agent among thienopyridine drugs. Clopidogrel, which acts as a prodrug, proves an effective inhibitor of platelet aggregation due to the selective and irreversible blocking of the P2Y12 receptor in the platelet cell membrane. Moreover, its intestinal absorption is limited by a bowel effusion P-glycoprotein pump encoded by the $A B C B 1$ gene $(1,2)$. Approximately $85 \%$ of this drug is hydrolyzed to an inactive metabolite by the esterases, while the remaining $15 \%$ is oxidized by the cytochrome P450 enzyme system and converted into active metabolite (thiol derivative-R-130964). As is well-known, the biotransformation of clopidogrel is made out of two steps. In addition, cytochrome P450 enzymes involved in clopidogrel biotransformation can be listed as CYP2C19, CYP2C9, CYP2B6, CYP3A4 and CYP1A2 $(1,2)$.

Situated in the $10^{\text {th }}$ chromosome (10q24.1-10q24.3), the genetic localization, where the CYP2C19 enzyme is coded, is 1.473 base pairs in length. This gene contains 9 exons and encodes a protein composed of 490 amino acids (1).

The Food and Drug Administration (FDA) describes the different alleles of CYP2C19 and their effects as follows: although the CYP2C19*1 allele is an ancestral type, it is a completely normal activity allele of clopidogrel, and also its clopidogrel metabolism is normal. Known as non-functional alleles of clopidogrel, CYP2C19*2 and CYP2C19*3 are termed as alleles deprived of a metabolism (clopidogrel resistance). The CYP2C19*4, CYP2C19*5, CYP2C19*6, CYP2C19*7 and CYP2C19*8 alleles may be deprived of clopidogrel metabolism or have low clopidogrel metabolism. With this warning, the FDA emphasizes that patients should be treated with clopidogrel by considering the genetic differences in CYP2C19 function (3).

The allele with normal activity is CYP2C19*1. On the other hand, the CYP2C19*2 polymorphism is the splicing damage mutation (rs4244285) resulting from the change of guanine adenine $(\mathrm{G} \rightarrow \mathrm{A})$ at nucleotide position 681 of the cDNA sequence in exon 5. Altering the reading frame of the mRNA that starts with the amino acid 215, this change forms a non-functional protein by creating a stop code in the downstream region with 20 amino acids $(1,2)$. The conversion of the prodrug clopidogrel into the active metabolite is inhibited, resulting in clopidogrel resistance.
To date, a considerable literature has grown up around the theme of the ethnic differences in the CYP2C19 genotype and its prevalence (4-15). It is now well established from a variety of studies that CYP2C19 gene polymorphism is associated with clopidogrel resistance in patients using clopidogrel due to CAD. In addition, the existing body of research suggests that there are differences in CYP2C19 genotype in the group with CAD.

To this respect, the specific objective of this study is to establish the CYP2C19*1 and CYP2C19*2 allele frequencies both in Turkish patients with CAD, who thus use clopidogrel, and in healthy Turkish population as well as to present the differences in genotypes and alleles between both groups.

\section{Materials and Methods}

Having been approved by the Pamukkale University Ethics Committee, the study included 100 healthy volunteers and 200 patients diagnosed with CAD and using clopidogrel, all of whom lived in Denizli. A total of 300 individuals (100 controls and 200 patients) were informed about the informed consent of the Helsinki Declaration. All the individuals and patients consented, in writing, for the study after full explanation of what was involved. Written consent form was signed by all the participants (patients and control groups). This study is a prospective case-control study.

\section{Data Collection}

The data of the patients' age, gender and number of angiographic interventions were recorded in the data set.

\section{Blood collection and DNA isolation}

Initially, genomic DNA was isolated with standard phenolchloroform method by taking blood into the anticoagulated (K3EDTA) vacuum tubes. Subsequently, the region specific to the CYP2C19gene was amplified through the polimerase chain reaction method in the genomic DNAs obtained, and the polymorphic foci in these regions were specified (4).

\section{Statistical Analysis}

SPSS statistical software version 23.0 was used for data analysis. Goodness of fit test was used for analyzing the distribution of the alleles and genotypes. Fisher's Exact and chi-square tests were used to compare the allele and genotype frequencies. Descriptive analysis was used to compare allele frequencies between the Turkish population and published data of other ethnic groups. A value of $p<0.05$ was considered as statistically significant. 


\section{Results}

Table 1 presents the breakdown of data for the CAD group and the control group as well as the data for the Goodness of fit test according to the Hardy Weinber distribution. When the CAD patients and control group were evaluated together, CYP2C19*1/1 genotype was detected in 204 subjects $(68 \%)$, followed by CYP2C19*1/2 genotype in 82 subjects (27.3\%) and CYP2C19*2/2 genotype in 14 subjects (4.6\%).

The CYP2C19*1 allele frequency was $490(81.6 \%)$, whereas that of CYP2C19*2 was 110 (18.3\%). As far as the genotype frequencies of the groups were concerned, CYP2C19*1/1 genotype was found in 132 patients (66\%), CYP2C19*1/2 genotype in 62 patients (31\%) and CYP2C19*2/2 genotype in 6 patients $(3 \%)$ in the CAD group. On the other hand, there were 72 subjects $(72 \%)$ with CYP2C19*1/1 genotype, 20 subjects with CYP2C19*1/2 genotype and 8 subjects with CYP2C19*2/2 genotype in the control group. A significant difference was found between the groups in terms of genotypes $(\mathrm{p}=0.034)$. The CYP2C19*1/1 genotype was found at higher percentages in the control group, whereas its CYP2C19*2/2 counterpart had a higher proportion in the CAD group (Table 2).

When it comes to the allele frequencies of the groups, the CYP2C19*1 allele frequency was $326(81.5 \%)$ and that of CYP2C19*2 was $74(19.5 \%)$ in the CAD group, while CYP2C19*1 allele frequency was $164(82 \%)$ and that of CYP2C19*2 was 36 (18\%) in the control group. No significant difference was found between the groups in terms of allele frequencies, which were similar in both groups $(\mathrm{p}=0.881$ ) (Table 2).

Table 3-5 presents an overview of the data in other studies in which CYP2C19*1 and CYP2C19*2 genotype and alleles frequencies were investigated. The differences in these genotypes and alleles frequencies between our study and these studies can also be seen in these tables (4-23).

With respect to the relationship between the number of angiographic interventions and genotypes of the patients, 120 (90.9\%) of the patients with CYP2C19*1/1 genotype underwent angiography only once, whereas $12(9.9 \%)$ were exposed to angiography twice or more and to medical Table 1. Non-parametric chi-square "goodness of fit" test

\begin{tabular}{|c|c|c|c|c|c|c|}
\hline & & \multicolumn{5}{|c|}{ CAD group } \\
\hline & & Observed & Expected & $\begin{array}{l}\text { Expected } \\
\text { proportion }\end{array}$ & $\begin{array}{l}\text { Percentage } \\
\text { deviation }\end{array}$ & $\begin{array}{l}\text { Standardized } \\
\text { residuals }\end{array}$ \\
\hline \multirow[t]{6}{*}{ CYP2C19*2 } & $* 1 / *_{1}$ & 132 & 132.85 & 0.66425 & $-0.64 \%$ & -0.07 \\
\hline & $* 1 / * 2$ & 62 & 60.31 & 0.30155 & $+2.8 \%$ & +0.22 \\
\hline & $* 2 / * 2$ & 6 & 6.85 & 0.03425 & $-12.41 \%$ & -0.32 \\
\hline & & \multicolumn{5}{|c|}{$X^{2}=0.16, d f=2, p=0.9231$} \\
\hline & & \multicolumn{5}{|c|}{$\begin{array}{l}\text { Control group } \\
n=100 \text { subjects, } n=200 \text { alleles }\end{array}$} \\
\hline & & Observed & Expected & $\begin{array}{l}\text { Expected } \\
\text { proportion }\end{array}$ & $\begin{array}{l}\text { Percentage } \\
\text { deviation }\end{array}$ & $\begin{array}{l}\text { Standardized } \\
\text { residuals }\end{array}$ \\
\hline \multirow[t]{4}{*}{ CYP2C19*2 } & $* 1 / * 1$ & 72 & 67.24 & 0.6724 & $+7.08 \%$ & +0.58 \\
\hline & $* 1 / * 2$ & 20 & 29.52 & 0.2952 & $-32.25 \%$ & -1.75 \\
\hline & $* 2 / * 2$ & 8 & 3.24 & 0.0324 & $+146.91 \%$ & +2.64 \\
\hline & & \multicolumn{5}{|c|}{$X^{2}=10.4, d f=2, p=0.0055$} \\
\hline
\end{tabular}

CAD: Coronary artery disease

Table 2. Allele frequencies of CYP2C19*1 and *2 in CAD and control groups

\begin{tabular}{|c|c|c|c|c|c|c|c|c|c|}
\hline \multicolumn{5}{|c|}{$\begin{array}{l}\text { CAD group } \\
n=200 \text { subjects, } n=400 \text { alleles }\end{array}$} & \multicolumn{5}{|c|}{$\begin{array}{l}\text { Control group } \\
n=100 n=200 \text { alleles }\end{array}$} \\
\hline \multirow{2}{*}{$\begin{array}{l}\text { Genotype } \\
*_{1} 1 / 1\end{array}$} & \multirow{2}{*}{$\begin{array}{l}\mathbf{n}(\%) \\
132(66)\end{array}$} & \multicolumn{2}{|c|}{ Allele frequency } & \multirow{2}{*}{$\begin{array}{l}\mathbf{p} \\
0.032\end{array}$} & \multirow{2}{*}{$\begin{array}{l}\text { Genotype } \\
* 1 / 1\end{array}$} & \multirow{2}{*}{$\begin{array}{l}\mathbf{n}(\%) \\
72(72)\end{array}$} & \multicolumn{2}{|c|}{ Allele frequency } & \multirow{2}{*}{$\begin{array}{l}\mathbf{p} \\
0.881\end{array}$} \\
\hline & & $*_{1}$ & $81.5 \%$ & & & & $* 1$ & $82 \%$ & \\
\hline$* 1 / 2$ & $62(31)$ & $* 2$ & $19.5 \%$ & & $* 1 / 2$ & $20(20)$ & $* 2$ & $18 \%$ & \\
\hline$* 2 / 2$ & $6(3)$ & & & & $* 2 / 2$ & $8(8)$ & & & \\
\hline
\end{tabular}

p-values are derived from Fisher's Exact test, CAD: Coronary artery disease 
interventions during angiography. While $53(77 \%)$ of the patients (CYP2C19*1/2 and CYP2C19*2/2) carrying the CYP2C19*2 allele underwent one angiography, $15(23 \%)$ patients were subjected to 2 or more angiomas. Bearing the CYP2C19*2 allele heightened the risk of multiple angiographic interventions in the patient group by 2.83 times [ $\mathrm{p}=0.16$ and $95 \%$ confidence interval (CI) (1.24-6.45)] (Table 6).

\section{Discussion}

In 2017, the United States FDA issued some warnings on clopidogrel metabolism and the impact of the CYP2C19 gene on this metabolism. In accordance with these warnings, it was reported that some patients might metabolize clopidogrel more poorly, and that clopidogrel activity would decrease in these patients (24).

In addition, FDA also warned that the CYP2C19*1 allele provides normal functional metabolism of clopidogrel, while CYP2C19*2 and CYP2C19*3 alleles cause dysfunction in the metabolism of clopidogrel. It was noted that if patients carry both of these non-functional alleles, they can be designated as poor metabolizers, whereas intermediate metabolizers are those who carry one copy of CYP2C19 encoding a non-functional allele, which might be either * 1 or *2 (25).

There is a large body of literature that recognizes the variability of CYP2C19 gene polymorphism in different ethnicities in healthy volunteers. As noted before, CYP2C19*1 allele frequency turns out to be $82 \%$, while CYP2C19*2 allele frequency is $18 \%$ for healthy volunteers (control group) in our study. In contrast, CYP2C19*1 allele frequency is reported as $56 \%-74 \%$ and CYP2C19*2 allele frequency as $24 \%$ and $37 \%$ in the studies aimed at Chinese and Thai population $(8-11,13)$. Our study is different from the Chinese and Thai populations in terms of * 1 and ${ }^{*} 2$ allele frequencies and healthy group population. For

\section{Table 3. CYP2C19 gene genotypes and allele frequencies of healthy group in different populations}

\begin{tabular}{|c|c|c|c|c|c|c|c|c|}
\hline Population & Subjects N & Alleles $\mathbf{N}$ & $* 1 / 1$ & $* 1 / 2$ & $* 2 / 2$ & $*_{1}$ & $* 2$ & Reference \\
\hline Ethiopian & 114 & 228 & 0.746 & 0.193 & 0.026 & 0.842 & 0.122 & 4 \\
\hline Zimbabwean & 84 & 168 & 0.773 & 0.190 & 0.035 & 0.869 & 0.130 & 5 \\
\hline Chinese-Han & 101 & 202 & 0.316 & 0.465 & $N / E$ & 0.56 & 0.37 & 7 \\
\hline Chinese-Li & 100 & 200 & 0.48 & 0.49 & 0 & 0.740 & 0.245 & 8 \\
\hline Chinese-Hakka & 6.686 & 13,372 & 0.417 & 0.396 & 0.097 & 0.64 & 0.31 & 11 \\
\hline Belgium & 121 & 242 & 0.835 & 0.149 & 0.016 & 0.909 & 0.091 & 12 \\
\hline Beninese & 111 & 222 & 0.739 & 0.261 & 0 & 0.87 & 0.13 & 12 \\
\hline Palestinian & 100 & 200 & 0.81 & 0.19 & 0 & 0.905 & 0.095 & 13 \\
\hline Turkish & 160 & 320 & 0.655 & 0.234 & 0.110 & 0.88 & 0.12 & 15 \\
\hline Turkish (present study) & 100 & 200 & 0.72 & 0.20 & 0.08 & 0.82 & 0.18 & - \\
\hline
\end{tabular}

Table 4. CYP2C19 gene genotypes and allele frequencies in coronary artery disease population

\begin{tabular}{|c|c|c|c|c|c|c|c|c|}
\hline Population & Subjects $\mathbf{N}$ & Alleles $\mathbf{N}$ & $* 1 / 1$ & $* 1 / 2$ & $* 2 / 2$ & $* 1$ & $* 2$ & Reference \\
\hline Egyptian & 230 & 460 & 75.2 & 23.1 & 1.7 & 86.7 & 13.3 & 16 \\
\hline Russian & 81 & 162 & 84 & 16 & 0 & 92 & 8.0 & 17 \\
\hline Yakutsk (Russia) & 268 & 536 & 65.67 & 33.58 & 0.075 & 82.46 & 17.54 & 18 \\
\hline Russian & 143 & 286 & 83.92 & 15.38 & 0.070 & 91.60 & 8.40 & 18 \\
\hline Chinese & 168 & 336 & 44.05 & 41.67 & 14.28 & 64.89 & 35.11 & 19 \\
\hline Chinese-Hakka & 934 & 1868 & 40.36 & 40.26 & 9.42 & 63.17 & 31.64 & 11 \\
\hline Turkish & 347 & 694 & 72.9 & 23.6 & 3.5 & 84.7 & 15.3 & 20 \\
\hline Turkish (present study) & 200 & 400 & 66.0 & 31.0 & 3.0 & 81.5 & 19.5 & - \\
\hline
\end{tabular}


instance, ${ }^{*} 1$ allele frequency is higher than Chinese and Thai population, although that of *2 is lower in our study group. As far as the studies on African black race (Ethiopian, Zimbabwean, Beninese) are concerned, * 1 allele frequency proves to be lower, whereas that of * 2 is higher than our study $(4,5,12)$. Previous research on European-Caucasian population (Italian, Belgium, German) establishes*1 allele frequency to be in the range of $84 \%-90.9 \%$, while that of *2 is in the range of $9.1 \%-23 \%(10,12,14) .{ }^{*} 1$ allele frequency reported in the existing study is lower than the percentages in Italian, Belgium and German population, but that of *2 is higher $(10,12,14)$. Even though the allele frequencies in the healthy group are similar to those of the previous studies on the European, Turkish and Caucasian population, ${ }^{*} 2$ allele frequencies turn out to be higher in our study $(10,12-15)$.

With respect to the genotype frequencies in the studies on ethnic diversity, ${ }^{*} 1 / 1$ genotype frequency is reported to be in the $31.6 \%-41.9 \%$ range, whereas ${ }^{*} 2 / 2$ genotype frequency is in the range of $0 \%-9.7 \%$ in the Chinese population $(6-8,11)$. In contrast to $* 1 / 1$ genotype frequency in the current study which is noticeably different from the Chinese population, ${ }^{*} 2 / 2$ genotype frequency seems to be in similar percentages both in our study's participants and in Chinese population (6-8). The last but not the least, * $1 / 1$ genotype frequency is considerably higher in our healthy volunteer group than in the Chinese population, while that of * $1 / 2$ is lower (6-8).

Research on the Caucasian population (Italian, Belgium, German) specifies * $1 / 1$ genotype frequencies to be between $70.6 \%$ and $83.5 \%{ }^{*} 1 / 1$ genotype frequencies in our healthy volunteers are akin to the Caucasian population data unlike those of $* 2 / 2$ which are higher in our healthy volunteers within our study than the aforementioned studies on the Caucasian population $(10,12,14)$.

The earlier studies on the Turkish population have identified*1/1 genotype frequency as $65.5 \%-76 \%$. On

\begin{tabular}{|c|c|c|c|c|c|c|c|c|}
\hline \multirow[t]{2}{*}{ Population } & \multirow[t]{2}{*}{ Group (N) } & \multicolumn{3}{|c|}{ Genotypes N (\%) } & \multicolumn{2}{|c|}{ Alleles (\%) } & \multirow[t]{2}{*}{ p } & \multirow[t]{2}{*}{ Ref. no } \\
\hline & & $* 1 / 1$ & $* 1 / 2$ & $* 2 / 2$ & $*_{1}$ & $* 2$ & & \\
\hline \multirow{4}{*}{ Russian } & CAD & 448 & 106 & 7 & 802 & 107 & \multirow{4}{*}{0.086} & \multirow{4}{*}{21} \\
\hline & (561) & $(79.9)$ & $(18.9)$ & $(1.2)$ & 09.3 & 10.1 & & \\
\hline & Control & 543 & 130 & 21 & & & & \\
\hline & (694) & $(78.2)$ & $(18.7)$ & $(3.0)$ & 87.6 & 12.4 & & \\
\hline \multirow{4}{*}{ Russian } & CAD & 69 & 14 & 1 & 005 & 05 & \multirow{4}{*}{0.42} & \multirow{4}{*}{22} \\
\hline & (84) & $(82.1)$ & $(16.7)$ & $(1.2)$ & 90.5 & 9.5 & & \\
\hline & Control & 23 & 6 & 1 & & & & \\
\hline & (30) & $(76.7)$ & $(20.0)$ & (3.3) & 86.7 & 13.3 & & \\
\hline \multirow{4}{*}{$\begin{array}{l}\text { Kazakh } \\
\text { Slav }\end{array}$} & CAD & 50 & 22 & م0 & 025 & 175 & \multirow{4}{*}{ N/A } & \multirow{4}{*}{23} \\
\hline & (72) & $(69.4)$ & $(30.6)$ & 0.0 & 02.0 & 16.0 & & \\
\hline & Control & 179 & 71 & 5 & & & & \\
\hline & (255) & $(70.0)$ & $(28.0)$ & $(2.0)$ & 84.7 & 15.3 & & \\
\hline \multirow{4}{*}{ Turkish (present study) } & CAD & 132 & 62 & 6 & & 5 & \multirow{4}{*}{$* 0.034$} & \multirow{4}{*}{-} \\
\hline & $(200)$ & $(66.0)$ & $(31.0)$ & (3.0) & 81.5 & 19.5 & & \\
\hline & Control & 72 & 20 & 8 & & & & \\
\hline & $(100)$ & $(72.0)$ & $(20.0)$ & $(8.0)$ & 82.0 & 18.0 & & \\
\hline
\end{tabular}

CAD: Coronary artery disease

Table 6. Genotypes and number of angiographic interventions

\begin{tabular}{lllll} 
Number of intervention & Genotypes & p & 95\% Cl \\
\hline & CYP2C19*1/1 & CYP2C19*1/2 \& CYP2C19* 2/2 & \\
$\mathbf{n}(\%)$ & $\mathbf{n}(\%)$ & 53 & 0.016 & 2.83 \\
\hline $\mathbf{1}$ & 120 & $(77 \%)$ & $(1.24-6.4)$ \\
& $(90.9 \%)$ & 15 & $(23 \%)$ & \\
\hline
\end{tabular}

$\mathrm{p}$-value is derived from chi-square test, $\mathrm{Cl}$ : Confidence interval 
the contrary, a study comparing Palestinian and Turkish populations reports no presence of genotype of *2/2 (13), though some findings in earlier studies establish*2/2 genotype frequency in healthy Turkish population to be around $10 \%$. The results of healthy volunteers in our study seem to be consistent with the data of previous research with regard to both ${ }^{*} 1 / 1$ and $* 2 / 2$ genome frequencies (1315).

When it comes to the CAD group within our study, ${ }^{*} 1$ allele frequency is $81.5 \%$, while that of $* 2$ is $19.5 \%$. Considering the allele frequencies concerning ethnicity, ${ }^{*} 2$ allele frequency is lower in our study group than that reported by the previous studies on Chinese $(11,19)$. In addition, *2 allele frequency in the Russian and Egyptian populations is reported as 8\% and $13.3 \%$, respectively $(16,17)$. As can be noticed from the above-mentioned research, the percentages of *2 allele observed in this investigation are far above those observed by in these studies. However, earlier research on the Turkish CAD population has reported ${ }^{*} 2$ allele frequency as $15.9 \%$, consistent with the present data in our study (20).

With respect to genotype frequencies in CAD patients, * $1 / 1$ genotype frequency in the Chinese populations is lower than the patients in our study, whereas *2/2 genotype frequency is higher $(11,19)$. In Russian and Russian-Yakutsk population, ${ }^{*} 2 / 2$ genotype frequency is lower than our patient group $(17,18)$. Moreover, genotype frequencies in our study are of similar nature to the previous study conducted on the Turkish population with CAD (20).

Studies comparing genotype and allele frequencies in individuals with $\mathrm{CAD}$ and healthy population report no difference in allele or genotype between control and CAD groups. However, a closer look into the pertaining studies will reveal the noticeable impact of the number of patients included in studies, and it is observed that as the number of patients increase, $p$ value gets closer to the significance level (21-23). In our study, although no difference exists between the groups in terms of alleles in CAD group, there is a difference in genotypes in CAD group, which is mainly caused by the intermediate group. This case highlights the importance of checking CYP2C19 gene polymorphism prior to the initiation of antiplatelet therapy in CAD patients.

As a review of current literature suggests, CYP2C19*2 allele is one of the overriding factors contributing to clopidogrel resistance (3). Having followed-up 1050 patients for cardiovascular diseases for 8 years, Rothenbacher et al. (26) concluded that the CYP2C19*2/2 genotype poses a risk for the development of cardiovascular diseases. Likewise, a meta-analysis by Singh et al. (27) revealed that CYP2C19*2 polymorphism might heighten the risk of stent thrombosis by 2.4 times (RR: 2.41, CI: 1.69-3.41, p<0.001). On the other hand, Nozari et al. (28) found that the risk of restenosis did not increase in individuals with CYP2C19*1/CYP2C19*2 genotype within one year.

Our study reveals that carrying CYP2C19*2 polymorphism (heterozygous or homozygous) may heighten the risk of secondary angiographic intervention. Although the number of our patients bearing homozygous polymorphism is highly low, our study may be considered as an important step towards unraveling the relationship between CYP2C19*2 polymorphism and increased risk of restenosis.

\section{Study Limitations}

Some limitations are inherent in our study. For example, we did not analyze alleles and genotype differences except CYP2C19*1 and $* 2$ in our study. Further, we did not carry out the clinical follow-up of the patients in our study as well as not measuring clopidogrel metabolite.

\section{Conclusion}

As a conclusion, in our research, we studied CYP2C19 gene polymorphism and CYP2C19*1 and CYP2C19*2 allele frequencies in the control group with 100 healthy volunteers and 200 CAD patients. In addition, the high frequency of percutaneous coronary intervention in individuals with CYP2C19*2 allele suggests that clopidogrel resistance is likely to pose an important challenge. CYP2C19*1/2 and *2/2 genotypes were found to be higher in CAD patients than the one in the control group, underlining how critical checking CYP2C19 gene polymorphism is before setting out antiplatelet therapy in CAD patients.

\section{Ethics}

Ethics Committee Approval: Having been approved by the Pamukkale University Ethics Committee, the study included 100 healthy volunteers and 200 patients diagnosed with CAD and using clopidogrel, all of whom lived in Denizli.

Informed Consent: Written consent form was signed by all the participants

Peer-review: Externally peer-reviewed.

\section{Authorship Contributions}

Concept: A.K., R.S., Design: A.K., İ.D.K., A.Y., Data Collection or Processing: A.Y., İ.D.K., A.K., Analysis or Interpretation: R.S., A.Y., İ.D.K., Literature Search: A.K., A.Y., Writing: R.S. 
Conflict of Interest: No conflict of interest was declared by the authors.

Financial Disclosure: The authors declared that this study received no financial support.

\section{References}

1. De Morais, SM, Wilkinson, GR, Blaisdell, Meyer UA, Nakamura K, Goldstein JA. Identification of a new genetic defect responsible for the polymorphism of (S)-mephenytoin metabolism in Japanese. Mol Pharmacol 1994;46(4):594-598.

2. De Morais SM, Wilkinson GR, Blaisdell, Nakamura K, Meyer UA, Goldstein JA. The major genetic defect responsible for the polymorphism of S-mephenytoin metabolism in humans. J Biol Chem 1994;269(22):15419-15422.

3. Holmes DR Jr, Dehmer GJ, Kaul S, Leifer D, O'Gara PT, Stein MC. ACCF/AHA clopidogrel clinical alert: approaches to the FDA "boxed warning": a report of the American College of Cardiology Foundation Task Force on clinical expert consensus documents and the American Heart Association endorsed by the Society for Cardiovascular Angiography and Interventions and the Society of Thoracic Surgeons. J Am Coll Cardiol 2010;56(4):321-341.

4. Persson I, Aklillu E, Rodrigues F, Bertilsson L, Ingelman-Sundberg M. S-mephenytoin hydroxylation phenotype and CYP2C19 genotype among Ethiopians. Pharmacogenetics 1996;6(6):521526.

5. Masimirembwa C, Bertilsson L, Johansson I, Hasler A, IngelmanSundberg M. Phenotyping and genotyping of S-mephenytoin hydroxylase (cytochrome P450 2C19) in a Shona population of Zimbabwe. Clin Pharmacol Ther 1995;57(6):656-661.

6. He N, Yan FX, Huang SL, Wang W, Xiao ZS, Liu ZQ, et al. CYP2C19 genotype and S-mephenytoin 4'-hydroxylation phenotype in a Chinese Dai population. Eur J Clin Pharmacol 2002;58(1):15-18.

7. Xiao ZS, Goldstein JA, Xie HG, Blaisdell J, Wang W, Jiang CH, et al. Differences in the incidence of the CYP2C19 polymorphism affecting the S-mephenytoin phenotype in Chinese Han and Bai populations and identification of a new rare CYP2C19 mutant allele. J Pharmacol Exp Ther 1997;281(1):604-609.

8. Ding Y, Xu D, Zhang X, Yang H, Geng T, He P, et al. Genetic polymorphisms and phenotypic analysis of drug-metabolizing enzyme CYP2C19 in a Li Chinese population. Int J Clin Exp Pathol 2015;8(10):13201-13208.

9. Sukasem C, Tunthong $\mathrm{R}$, Chamnanphon $\mathrm{M}$, Santon $\mathrm{S}$, Jantararoungtong T, Koomdee N, et al. CYP2C19 polymorphisms in the Thai population and the clinical response to clopidogrel in patients with atherothrombotic-risk factors. Pharmgenomics Pers Med 2013;6:85-91.

10. Scordo MG, Caputi AP, D’Arrigo C, Fava G, Spina E. Allele and genotype frequencies of CYP2C9, CYP2C19 and CYP2D6 in an Italian population. Pharmacol Res 2004;50(2):195-200.

11. Zhong Z, Hou J, Li B, Zhange, Zhang Q, Liu S, Li C, et al. Analysis of CYP2C19 Genetic Polymorphism in a Large Ethnic Hakka Population in Southern China. Med Sci Monit 2017;23:6186-6192.

12. Allabi AC, Gala JL, Desager JP, Heusterspreute M, Horsmans Y. Genetic polymorphisms of CYP2C9 and CYP2C19 in the Beninese and Belgian populations. Br J Clin Pharmacol 2003;56(6):653657.
13. Nassar S, Amro O, Abu-Rmaileh H, Alshaer I, Korachi M, Ayeshb $S$, et al. ABCB1 C3435T and CYP2C19*2 polymorphisms in a Palestinian and Turkish population: A pharmacogenetic perspective to clopidogrel. Meta Gene 2014;2:314-319.

14. Aynacioglu AS, Sachse C, Bozkurt A, Kortunay S, Nacak M, Schröder $\mathrm{T}$, et al. Low frequency of defective alleles of cytochrome P450 enzymes 2C19 and 2D6 in the Turkish population. Clin Pharmacol Ther 1999;66(2):185-192.

15. Arici M, Özhan G. CYP2C9, CYPC19 and CYP2D6 gene profiles and gene susceptibility to drug response and toxicity in Turkish population. Saudi Pharm J 2017;25(3):376-380.

16. Fathy S, Shahin MH, Langaee T, Khalil BM, Saleh A, Sabry NA, et al. Pharmacogenetic and clinical predictors of response to clopidogrel plus aspirin after acute coronary syndrome in Egyptians. Pharmacogenet Genomics 2018;28(9):207-213.

17. Mirzaev KB, Rytkin E, Ryzhikova KA, Grishina EA, Sozaeva ZA, Fedorinov DS, et al. The ABCB1, CYP2C19, CYP3A5 and CYP4F2 genetic polymorphisms and platelet reactivity in the early phases of acute coronary syndromes. Drug Metab Pers Ther 2018;33(3):109118.

18. Fedorinov DS, Mirzaev KB, Ivashchenko DV, Temirbulatov II, Sychev DA, Maksimova NR, et al. Pharmacogenetic testing by polymorphic markers $681 \mathrm{G}>\mathrm{A}$ and $636 \mathrm{G}>\mathrm{A}$ CYP2C19 gene in patients with acute coronary syndrome and gastric ulcer in the Republic of Sakha (Yakutia). Drug Metab Pers Ther 2018;33(2):9198.

19. Li X, Wang Z, Wang Q, Xu Q, Lv Q. Clopidogrel-associated genetic variants on inhibition of platelet activity and clinical outcome for acute coronary syndrome patients. Basic Clin Pharmacol Toxicol 2019;124:84-93.

20. Saydam F, Değirmenci İ, Birdane A, Özdemir M, Ulus T, Özbayer C, et al. The CYP2C19*2 and CYP2C19*17 Polymorphisms play a Vital Role in Clopidogrel Responsiveness after Percutaneous Coronary Intervention: A Pharmacogenomics Study. Basic Clin Pharmacol Toxicol 2017;121(1):29-36.

21. Polonikov A, Kharchenko A, Bykanova M, Svetlana Sirotina 4, Irina Ponomarenko 4, Anna Bocharova, et al. Polymorphisms of CYP2C8, CYP2C9 and CYP2C19 and risk of coronary heart disease in Russian population. Gene 2017;627:451-459.

22. Grinshtein YI, Kosinova AA, Grinshtein IY, Subbotina TN, Savchenko AA. The Prognostic Value of Combinations of Genetic Polymorphisms in the ITGB3, ITGA2, and CYP2C19*2 Genes in Predicting Cardiovascular Outcomes After Coronary Bypass Grafting. Genet Test Mol Biomarkers 2018;22(4):259-265.

23. Smagulova G, Kulmurzaeva N, Seytmaganbetova N, Kurmanalina G, Talipova I. The First Results of the Prevalence of CYP2C19 Gene Polymorphism In Patients with Acute Coronary Syndrome In The Aktyubinsk Population. Georgian Med News 2016;(253):6166.

24. FDA Drug Safety Communication: Reduced effectiveness of Plavix (clopidogrel) in patients who are poor metabolizers of the drug 2017. From<https://www.fda.gov/drugs/drugsafety/ postmarketdrugsafetyinformationforpatientsandproviders/ ucm203888.htm\#AIHP> (Accessed on 07 January 2020)

25. Dean L. Clopidogrel Therapy and CYP2C19 Genotype. In Medical Genetics Summaries. USA: National Center for Biotechnology Information. 2012.

26. Rothenbacher D, Hoffmann MM, Breitling LP, Rajman I, Koenig W, Brenner H. Cytochrome P450 2C19*2 polymorphism 
in patients with stable coronary heart disease and risk for secondary cardiovascular disease events: results of a long-term follow-up study in routine clinical care. BMC Cardiovasc Disord 2013;13:61.

27. Singh M, Shah T, Adigopula S, Molnar J, Ahmed A, Khosla $\mathrm{S}$, et al. CYP2C19*2/ABCB1-C3435T polymorphism and risk of cardiovascular events in coronary artery disease patients on clopidogrel: is clinical testing helpful? Indian Heart J 2012;64(4):341-352.

28. Nozari Y, Vosooghi S, Boroumand M, Poorhosseini H, Nematipour E, Salarifar M, et al. The impact of cytochrome P450 2C19 polymorphism on the occurrence of one-year in-stent restenosis in patients who underwent percutaneous coronary intervention: A case-match study. Anatol J Cardiol 2015;15(5):348-353. 